\title{
IMPLEMENTASI ALGORITMA APRIORI PADA TRANSAKSI PENJUALAN BARANG (STUDI KASUS: TOKO ISNA KABUPATEN BINTAN)
}

\author{
${ }^{1}$ Iwan Purnomo, ${ }^{2}$ Heti Mulyani \\ Sekolah Tinggi Teknologi Indonesia, Jurusan Sistem Informasi \\ e-mail : ${ }^{1}$ purnomo.iwan@gmail.com, ${ }^{2}$ heti@ sttindonesia.ac.id
}

\begin{abstract}
ABSTRAK
Salah satu upaya untuk mengoptimalkan penjualan barang pada toko Isna adalah dengan mengolah data yang menumpuk menjadi sebuah informasi yang berguna. Pemanfaatan data penjualan yang tersimpan dalam basis data dapat dilakukan dengan membuat sebuah aplikasi yang mengimplementasikan algoritma apriori. Algoritma apriori merupakan salah satu jenis aturan asosiasi pada data mining untuk untuk menemukan aturan suatu kombinasi item pada suatu database transaksi penjualan barang.

Dalam perancangan aplikasi ini, metodologi penelitian menggunakan metode pengumpulan data yang terdiri dari observasi, wawancara dan studi kepustakaan. Metode pengembangan perangkat lunak menggunakan metode waterfall dan aplikasi yang dikembangkan menggunakan bahasa pemrograman Netbeans, MySQL Front sebagai basis data, dan Xampp sebagai servernya.

Hasil penelitian ini menunjukkan bahwa aplikasi yang dibangun mampu menghasilkan informasi yang dapat memberikan pengetahuan bagi pemilik maupun pengguna untuk meningkatkan efisiensi penempatan posisi barang dagangan sehingga dapat mengoptimalkan penjualan barang. Hal ini terbukti dari 10 sample yang diambil pada bulan April menghasilkan produk G, Susu Frisian Flag Straw $180 \mathrm{ml}$ dan Teh Celup Prendjak 50x25x2gr. Item item tersebut merupakan produk yang sering terjual secara bersamaan dalam transaksi penjualan.
\end{abstract}

Kata Kunci : Toko Isna, Transaksi Penjualan, Algoritma Apriori, Aturan Asosiasi, Waterfall

\section{l. PENDAHULUAN}

Teknologi informasi merupakan salah satu teknologi yang sedang berkembang dengan pesat pada saat ini. Dengan kemajuan teknologi informasi, pengaksesan terhadap data maupun informasi yang tersedia dapat berlangsung dengan cepat, efisien, dan akurat. Sehingga hal ini menuntut para pelaku bisnis pada penjualan retail (eceran) untuk bisa mengembangkan usaha mereka dan agar bisa bertahan dalam persaingan. Salah satu bisnis di bidang penjualan adalah toko yang berbentuk mini market dan swalayan

Toko Isna merupakan sebuah toko yang terletak di kawasan yang ramai dan berdekatan dengan kawasan industri Lobam kabupaten Bintan. Toko Isna bergerak dalam bidang penjualan kebutuhan sehari hari yang memiliki sistem seperti pada mini market yaitu pembeli mengambil sendiri barang yang dibutuhkan dari rak rak dagangan yang akan dibeli kemudian melakukan pembayaran di kasir.[4] Selama ini data penjualan yang tersimpan di dalam database dan output 
aplikasi toko tersebut belum dimanfaatkan secara maksimal untuk pengembangan strategi pemasaran dan meningkatkan efesiensi penempatan barang dagangan. Selama ini penyusunan tata letak barang di rak hanya berdasarkan pada persepsi pemilik toko saja. Misalnya letak gula yang berjauhan dengan teh maupun kopi dan sebagainya. Penyusunan item item tersebut bisa dioptimalkan satu sama lain untuk keperluan promosi supaya konsumen tertarik untuk membeli barang yang ada di toko tersebut. Berdasarkan uraian diatas, maka penulis melakukan penelitian di toko Isna dengan membuat sebuah aplikasi yang mengimplementasikan algoritma apriori untuk menemukan pola penjualan item item produk yang sering terjual secara bersamaan dalam sebuah transaksi oleh konsumen terutama konsumen di daerah kawasan industri Lobam Kabupaten Bintan. Sehingga penelitian ini diharapkan bisa membantu pemilik toko untuk mengatur penyusunan barang dagangannya secara maksimal.

\section{KAJIAN PUSTAKA}

\subsection{Data}

Menurut Adita Ayu Prawiyanti, Ramadhian Agus Triyono (2013:45) data adalah suatu bahan mentah yang kelak dapat diolah lebih lanjut untuk menjadi sesuatu yang lebih bermakna [5]. Data inilah yang nantinya akan disimpan dalam database. Data merupakan komponen dasar dari informasi yang akan diproses lebih lanjut untuk menghasilkan informasi. Data merupakan kumpulan kejadian yang diangkat dari suatu kenyataan. Data dapat berupa angka-angka, huruf-huruf atau simbol-simbol khusus atau gabungan darinya. Data mentah masih belum bisa bercerita banyak, sehingga perlu diolah lebih lanjut. Data merupakan masukan dari suatu model pengolahan data yang menghasilkan keluaran berupa informasi.

\subsection{Data Mining}

Data mining adalah suatu teknik untuk menggali informasi yang berharga yang tersimpan pada suatu database sehingga ditemukan suatu pola yang menarik dimana sebelumnya tidak diketahui. Data mining sering disebut sebagai Knowlegge Discovery in Database (KDD) [3]. Knowlegge Discovery in Database adalah kegiatan yang meliputi pengumpulan, pemakaian data, historis untuk menemukan keteraturan, pola atau hubungan dalam set data berukuran besar. Karakteristik data mining sebagai berikut:

1. Data mining berhubungan dengan penemuan sesuatu yang tersembunyi dan pola data tertentu yang tidak diketahui sebelumnya.

2. Data mining biasa menggunakan data yang sangat besar, biasanya data yang besar digunakan untuk membuat hasil lebih dipercaya.

3. Data mining berguna untuk membuat keputusan yang kritis, terutama dalam strategi.

Budiono dkk (2014) menjelaskan bahwa proses Knowledge Discovery in Databases (KDD) secara garis besar adalah sebagai berikut:

1. Data Selection, merupakan pemilihan (seleksi) data dari sekumpulan data operasional perlu dilakukan sebelum tahap penggalian informasi dalam KDD. Data hasil seleksi yang akan digunakan untuk proses data mining, disimpan dalam suatu berkas, terpisah dari basis data operasional. 
2. Pre-processing/Cleaning.

Sebelum proses data mining dapat dilaksanakan, perlu dilakukan proses cleaning pada data yang menjadi focus KDD. Proses cleaning mencakup antara lain membuang duplikasi data, memeriksa data yang inkonsisten, dan memperbaiki kesalahan pada data, seperti kesalahan cetak (tipografi).

3. Integrasi data (Data Intregration).

Integrasi data merupakan penggabungan data dari berbagai database ke dalam satu database baru.

4. Transformasi Data (Data Transformation).

Coding adalah proses transformasi pada data yang telah dipilih, sehingga data tersebut sesuai untuk proses data mining. Proses coding dalam KDD merupakan proses kreatif dan sangat tegantung pada jenis atau pola informasi yang akan dicari dalam basis data.

5. Data Mining.

Data mining adalah proses mencari pola atau informasi menarik dalam data terpilih dengan menggunakan teknik atau metode tertentu. Teknik, metode, atau algoritma dalam data mining sangat bervariasi. Pemilihan metode atau algoritma yang tepat sengat bergantung pada tujuan dan proses KDD secara keseluruhan.

6. Interpretation/Evaluation.

Pola informasi yang dihasilkan dari proses data mining perlu ditampilkan dalam bentuk yang mudah dimengerti oleh pihak yang berkepentingan. Tahap ini merupakan bagian dari proses KDD yang disebut interpretation. Tahap ini mencakup pemeriksaan apakah pola atau informasi yang ditemukan bertentangan dengan fakta atau hipotesis yang ada sebelumnya.

7. Presentasi Pengetahuan.

Merupakan visualisasi dan penyajian pengetahuan mengenai teknik yang digunakan untuk memperoleh pengetahuan yang diperoleh pengguna. Tahap terakhir dari proses data mining adalah bagaimana memformulasikan keputusan atau aksi dari hasil analisa yang didapat.

Retno Tri Vulandari (2017:4) dalam bukunya mengemukakan bahwa data mining atau penambangan data dibagi menjadi beberapa teknik/kelompok berdasarkan tugas dan fungsinya, seperti:[2]

1. Klasifikasi(Clasification)

Proses untuk menemukan model atau fungsi yang menjelaskan konsep atau kelas data dengan tujuan untuk mendapatkan perkiraan kelas dari suatu objek yang labelnya tidak diketahui.

2. Clustering

Clustering merupakan proses pengelompokan sejumlah data/obyek kedalam kelompok data sehingga setiap kelompok berisi data yang memiliki kemiripan. Clustering melakukan pengelompokan data tanpa berdasarkan kelas data tertentu. Prinsip dari clustering adalah memaksimalkan kesamaan anggota satu kelas/cluster.

3. Asosiasi( Association)

Assosiation merupakan teknik mining untuk menemukan aturan asosiasi antara suatu kombinasi item dalam suatu waktu. 


\subsection{Analisis Asosiasi (Association rule)}

Analisis asosiasi atau association rule mining adalah teknik data mining untuk menemukan aturan suatu kombinasi item. Analisis asosiasi dikenal juga sebagai teknik data mining yang menjadi dasar dari berbagai teknik data mining lainnya. Khususnya salah satu tahap dari analisis asosiasi yang disebut analisis pola frekuensi tinggi (frequent patern mining) menarik perhatian banyak peneliti untuk menghasilkan algoritma yang efesien (Retno Tri Vulandari, 2017).

Penting tidaknya suatu aturan asosiasi dapat diketahui dengan dua parameter, support (nilai penunjang) yaitu persentasi kombinasi item tersebut dalam database dan confidence (nilai kepastian) yaitu kuatnya hubungan antar item dalam aturan asosiasi. Aturan asosiasi biasanya dinyatakan dalam bentuk :

$\{$ roti, mentega $\} \rightarrow\{$ susu $\}$ (support $=40 \%$, confidence $=50 \%$ ). Yang artinya: $50 \%$ dari transaksi di database yang memuat item roti dan mentega juga memuat item susu. Sedangkan $40 \%$ dari seluruh transaksi yang ada di database memuat ketiga item itu. Dapat juga diartikan: Seorang konsumen yang membeli roti dan mentega punya kemungkinan 50\% untuk juga membeli susu. Aturan ini cukup signifikan karena mewakili $40 \%$ dari catatan transaksi selama ini. Analisis asosiasi didefinisikan suatu proses untuk menemukan semua aturan asosiasi yang memenuhi syarat minimum untuk support (minimum support) dan syarat minimum untuk confidence (minimum confidence).

Retno Tri Vulandari (2017:66) juga menjelaskan bahwa metodologi dasar analisis asosiasi terbagi menjadi dua tahap yaitu:

1. Analisa pola frekuensi tinggi

Tahap ini mencari kombinasi item yang memenuhi syarat minimum dari nilai support dalam database. Nilai support sebuah item diperoleh dengan memakai rumus berikut:

$$
\text { Support }(\mathrm{A})=\frac{\text { Jumlah transaksi mengandung A }}{\text { Total transaksi }}
$$

Sementara itu, nilai support dari 2 item diperoleh dari rumus berikut Support $(\mathrm{A}, \mathrm{B})=(\mathrm{A} \cap \mathrm{B})$

Support $(\mathrm{A}, \mathrm{B})=\underline{\text { Jumlah transaksi mengandung A dan B }}$ Total transaksi

2. Pembentukan Aturan Asosiasi

Setelah semua pola frekuensi tinggi ditemukan, barulah dicari aturan assosiatif yang memenuhi syarat minimum untuk confidence dengan menghitung confidence aturan asosiasi “ jika A maka B “. Nilai confidence dari aturan " jika A maka B "diperoleh dari rumus berikut:

$$
\text { Confidence }=\mathrm{P}(\mathrm{B} / \mathrm{A})=\frac{\text { Jumlah transaksi mengandung A dan } \mathrm{B}}{\text { Jumlah transaksi mengandung A }}
$$

\section{METODOLOGI PENELITIAN}

\subsection{Metodologi Pengumpulan Data}

Dalam kegiatan untuk memperoleh data pada penelitian skripsi ini, penulis menggunakan teknik pengumpulan data yang digunakan adalah sebagai berikut: 
1. Observasi

Melakukan observasi atau peninjauan tempat di Toko Isna sebelum pelaksanaan kegiatan pengumpulan data dengan mengadakan pengenalan terhadap objek skripsi, aktivitas kerja dan bahan kajian.

2. Wawancara

Melakukan wawancara secara langsung dengan pihak yang terlibat dalam sistem toko tersebut salah satunya adalah pemilik toko.

3. Studi Kepustakaan

Melakukan pengumpulan data secara tidak langsung dengan melakukan studi kepustakaan, yaitu dengan mengumpulkan data-data dan teori-teori dari berbagai buku atau literatur yang berhubungan dengan penulisan skripsi ini.

\subsection{Metode Pengembangan Perangkat Lunak}

Prosedur pengembangan yang digunakan pada aplikasi ini adalah menggunakan prosedur pengembangan model Waterfall. Metode Waterfall (Classic Life Cycle) yang menyarankan pengembangan perangkat lunak secara sistematik dan berurutan yang dimulai dari tingkatan sistem tertinggi dan berlanjut ke tahap analisis, desain, coding , testing atau pengujian dan pemeliharaan[6]. Model ini disebut dengan waterfall karena tahap demi tahap yang dilalui harus menunggu selesainya tahap sebelumnya dan berjalan berurutan.

\section{HASIL DAN PEMBAHASAN}

\subsection{Analisis Kelemahan Sistem}

Tahap yang dilakukan penulis dalam menganalisis data adalah dengan menentukan permasalahan yang terjadi dalam aplikasi. Dari hasil pengamatan yang dilakukan penulis adalah sebagai berikut :

1. Output dari aplikasi yang saat ini digunakan pada toko Isna belum dapat menampilkan laporan penempatan posisi tata letak barang yang lebih baik sesuai dengan kecenderungan pembelian yang dilakukan konsumen sesuai dengan aturan algoritma apriori.

2. Data penjualan yang tersimpan dalam database belum dimanfaatkan secara maksimal untuk pengembangan strategi pemasaran dan meningkatkan efesiensi penempatan posisi barang dagangan.

3. Belum adanya aplikasi dalam menganalisa data penjualan yang bertujuan untuk mendapatkan pola belanja konsumen sehingga tata letak barang dagangannya masih belum terorganisir dengan baik.

\subsection{Studi Kasus Analisis menggunakan Algoritma Apriori}

Data transaksi penjualan pada toko isna dapat diperoleh dari laporan penjualan atau database yang menyimpan histori transaksi penjualan, pada studi kasus ini penulis hanya mendapatkan laporannya, sehingga data dibawah ini hanya beberapa sample yang diambil penulis yaitu 10 transaksi di bulan april laporan penjualan detail.

Tabel 1 Data Transaksi Penjualan

\begin{tabular}{|c|l|l|}
\hline No. & $\begin{array}{l}\text { No. Struk Tr. } \\
\text { Penjualan }\end{array}$ & \multicolumn{1}{c|}{ Produk } \\
\hline 1 & 01000001 & Susu Frisian Flag Straw 180 ml, G. \\
\hline
\end{tabular}




\begin{tabular}{|c|l|l|}
\hline 2 & 01000002 & Ciptadent Cool Tube 120 gr, Pepsodent White 75 Gr \\
\hline 3 & 01000003 & G., Lifebouy Shp Strong \& Shiny 70 ml \\
\hline 4 & 01000004 & $\begin{array}{l}\text { Susu Frisian Flag Straw 180 ml, Teh Celup Prendjak } \\
\text { 50x25x2gr, Pepsodent White 75 Gr, G. }\end{array}$ \\
\hline 5 & 01000005 & $\begin{array}{l}\text { Susu Frisian Flag Straw } 180 \mathrm{ml}, \text { G., Teh Celup Prendjak } \\
50 x 25 x 2 \mathrm{gr}\end{array}$ \\
\hline 6 & 01000006 & Tootbrs Ciptadent Crystal Soft, Ciptadent Cool Tube 120 gr \\
\hline 7 & 01000007 & Susu Frisian Flag Straw 180 ml, G. \\
\hline 9 & 01000008 & $\begin{array}{l}\text { G., Tootbrs Ciptadent Crystal Soft, Teh Celup Prendjak 50 } \\
\text { 25x2gr, Ciptadent Cool Tube 120 gr }\end{array}$ \\
\hline 10 & 010000010 & $\begin{array}{l}\text { G., Teh Celup Prendjak 50 x25x2gr, Downy Love Passion } \\
\text { 20ml }\end{array}$ \\
\hline
\end{tabular}

Implementasi algoritma apriori diawali dengan scan data penjualan (lihat Tabel 1), kemudian pembentukan pola kombinasi dengan 1 pola kombinasi itemset (C1), 2 pola kombinasi itemset (C2) dan begitu seterusnya dan perhitungan nilai support setiap kombinasi itemset [7]. Minimal support yang ditentukan adalah 29 $\%$.

1. Pembentukan pola kombinasi 1 itemset (C1)

Proses pembentukan $\mathrm{C} 1$ atau disebut 1 Itemset dengan jumlah minimal support $=29 \%$. Rumus 1 itemset $(\mathrm{C} 1)$ dapat dituliskan sebagai berikut:

Support $(\mathrm{A})=\underline{\text { Jumlah transaksi mengandung A }} * 100 \%$

Total transaksi

Dari data transaksi penjualan diatas (tabel 1) dibentuk pola kombinasi itemset nya dengan rumus di atas, maka hasilnya pada tabel berikut ini :

Tabel 2 Pola kombinasi 1 itemset (C1)

\begin{tabular}{|l|c|c|}
\hline \multicolumn{1}{|c|}{ Itemset } & Jumlah & Support \\
\hline Susu Frisian Flag Straw 180 ml & $\mathbf{5}$ & $(\mathbf{5} / \mathbf{1 0}) * \mathbf{1 0 0 \%}=\mathbf{5 0 \%}$ \\
\hline Teh Celup Prendjak 50 x25x2gr & $\mathbf{5}$ & $\mathbf{( 5 / 1 0 ) * 1 0 0 \% = \mathbf { 5 0 \% }}$ \\
\hline G. & $\mathbf{8}$ & $\mathbf{( 8 / 1 0 ) * 1 0 0 \% = 8 0 \%}$ \\
\hline Pepsodent White 75 Gr & 2 & $(2 / 10) * 100 \%=20 \%$ \\
\hline Downy Love Passion 20ml & 1 & $(1 / 10) * 100 \%=10 \%$ \\
\hline Ciptadent Cool Tube 120 gr & $\mathbf{3}$ & $(\mathbf{3 / 1 0}) * \mathbf{1 0 0 \%}=\mathbf{3 0 \%}$ \\
\hline Tootbrs Ciptadent Crystal Soft & 2 & $(2 / 10) * 100 \%=20 \%$ \\
\hline Lifebouy Shp Strong \& Shiny 70 ml & 1 & $(1 / 10)^{*} 100 \%=10 \%$ \\
\hline
\end{tabular}

Dengan support minimal $29 \%$ pada hasil tabel 2 maka hanya 4(empat) pola kombinasi itemsets yang memenuhi support minimal. Seperti pada tabel dibawah ini:

Tabel 3 Pola kombinasi 1 itemset (C1) yang memenuhi support minimal

\begin{tabular}{|l|c|c|}
\hline \multicolumn{1}{|c|}{ Itemset } & Jumlah & Support \\
\hline Susu Frisian Flag Straw 180 ml & 5 & $(5 / 10) * 100 \%=50 \%$ \\
\hline Teh Celup Prendjak 50 x25x2gr & 5 & $(5 / 10)^{*} 100 \%=50 \%$ \\
\hline G. & 8 & $(8 / 10)^{*} 100 \%=80 \%$ \\
\hline Ciptadent Cool Tube 120 gr & 3 & $(3 / 10) * 100 \%=30 \%$ \\
\hline
\end{tabular}


2. Pembentukan pola kombinasi 2 itemset (C2)

Proses pembentukan $\mathrm{C} 2$ atau disebut dengan 2 Itemset dengan jumlah minimum support $=29 \%$ dapat diselesaikan dengan rumus berikut :

Support $(\mathrm{A}, \mathrm{B})=\underline{\text { Jumlah transaksi mengandung A dan B }} * 100 \%$ Total transaksi

Sehingga dari pola kombinasi 1 itemset (C1) di tabel 3 yang memenuhi support minimal dibentuk pola kombinasi 2 itemset (C2) dengan rumus diatas. Maka hasilnya pada tabel berikut ini :

Tabel 4 Pola kombinasi 2 itemset (C2)

\begin{tabular}{|l|c|l|}
\hline \multicolumn{1}{|c|}{ Itemset } & Jumlah & \multicolumn{1}{c|}{ Support } \\
\hline $\begin{array}{l}\text { Susu Frisian Flag Straw 180 ml, Teh } \\
\text { Celup Prendjak 50x25x2gr }\end{array}$ & $\mathbf{3}$ & $\mathbf{( 3 / 1 0} * \mathbf{1 0 0 \%}=\mathbf{3 0 \%}$ \\
\hline Susu Frisian Flag Straw 180 ml, G. & $\mathbf{5}$ & $(\mathbf{5 / 1 0}) * \mathbf{1 0 0 \%}=\mathbf{5 0 \%}$ \\
\hline $\begin{array}{l}\text { Susu Frisian Flag Straw } 180 \mathrm{ml} \text {, Ciptadent } \\
\text { Cool Tube 120 gr }\end{array}$ & 0 & $(0 / 10) * 100 \%=0 \%$ \\
\hline Teh Celup Prendjak 50x25x2gr, G. & $\mathbf{5}$ & $(\mathbf{5 / 1 0}) * \mathbf{1 0 0 \%}=\mathbf{5 0 \%}$ \\
\hline $\begin{array}{l}\text { Teh Celup Prendjak 50x25x2gr, Ciptadent } \\
\text { Cool Tube 120 gr, }\end{array}$ & 1 & $(2 / 10) * 100 \%=10 \%$ \\
\hline G., Ciptadent Cool Tube 120 gr & 1 & $(2 / 10) * 100 \%=10 \%$ \\
\hline
\end{tabular}

Minimal support yang ditentukan adalah $29 \%$, jadi kombinasi 2 itemset yang tidak memenuhi minimal support akan dihilangkan, maka hanya 3 pola kombinasi itemsets yang memenuhi support minimal. Maka hasilnya pada tabel berikut ini :

Tabel 5 Pola kombinasi 2 itemset (C2) yang memenuhi support minimal

\begin{tabular}{|l|c|c|}
\hline \multicolumn{1}{|c|}{ Itemset } & Jumlah & Support \\
\hline Susu Frisian Flag Straw 180 ml, G. & 5 & $(5 / 10)^{*} 100 \%=50 \%$ \\
\hline $\begin{array}{l}\text { Teh Celup Prendjak 50x25x2gr, Susu } \\
\text { Frisian Flag Straw 180 ml }\end{array}$ & 3 & $(3 / 10)^{*} 100 \%=30 \%$ \\
\hline Teh Celup Prendjak 50x25x2gr, G. & 5 & $(5 / 10)^{*} 100 \%=50 \%$ \\
\hline
\end{tabular}

3. Pembentukan pola kombinasi 3 itemset (C3)

Proses pembentukan $\mathrm{C} 3$ atau disebut dengan 3 Itemset dengan jumlah minimum support $=29 \%$ dapat diselesaikan dengan rumus berikut:

Support $(\mathrm{A}, \mathrm{B}, \mathrm{C})=\underline{\text { Jumlah transaksi mengandung A,B dan C }} * 100 \%$ Total transaksi

Sehingga dari pola kombinasi 2 itemset (C2) di tabel 5 yang memenuhi support minimal dibentuk pola kombinasi 3 itemset (C3) dengan rumus diatas. Maka hasilnya pada tabel berikut ini :

Tabel 6 Pola kombinasi 3 itemset (C3) yang memenuhi support minimal

\begin{tabular}{|l|c|c|}
\hline \multicolumn{1}{|c|}{ Itemset } & Jumlah & Support \\
\hline $\begin{array}{l}\text { Susu Frisian Flag Straw 180 ml, } \\
\text { Teh Celup Prendjak 50x25x2gr, } \\
\text { G. }\end{array}$ & 3 & $(3 / 10) * 100 \%=30 \%$ \\
\hline
\end{tabular}

Pola kombinasi selanjutnya tidak bisa dibentuk karena pola kombinasi 3(itemset) hanya 1(satu) itemset. 
4. Pembentukan Aturan Asosiasi

Setelah semua pola frekuensi tinggi ditemukan, barulah dicari aturan assosiatif yang memenuhi syarat minimum untuk confidence dengan menghitung confidence aturan assosiatif $\mathrm{A} \rightarrow \mathrm{B}$ dimana minimal confidence adalah $45 \%$. Nilai confidence dari aturan $\mathrm{A} \rightarrow \mathrm{B}$ diperoleh dari rumus berikut:

Confidence $=\mathrm{P}(\mathrm{B} / \mathrm{A})=\underline{\text { Jumlah transaksi mengandung A dan } \mathrm{B}} * 100$ Jumlah transaksi mengandung A

Pembentukan aturan asosiasi dibentuk dari pola kombinasi yang memenuhi support minimal dari tiap pola kombinasi. Berikut adalah aturan asosiasi yang dibentuk dari pola kombinasi 2 itemset.

Tabel 7 Aturan asosiasi yang dihasilkan dari 2 pola kombinasi itemset

\begin{tabular}{|l|c|c|c|}
\hline \multicolumn{1}{|c|}{ Rule } & Support & $\begin{array}{l}\text { Support } \\
\text { Itemset }\end{array}$ & Confidence \\
\hline $\begin{array}{l}\text { Jika Susu Frisian Flag Straw 180 ml } \\
\text { terjual maka Teh Celup Prendjak } \\
\text { 50x25x2gr terjual }\end{array}$ & 5 & 3 & $\left((3 / 5)^{*} 100\right)=60 \%$ \\
\hline $\begin{array}{l}\text { Jika Susu Frisian Flag Straw 180 ml } \\
\text { terjual maka G. terjual }\end{array}$ & 5 & 5 & $\left((5 / 5)^{*} 100\right)=100 \%$ \\
\hline $\begin{array}{l}\text { Jika Teh Celup Prendjak 50x25x2gr } \\
\text { terjual maka Susu Frisian Flag Straw 180 } \\
\text { ml terjual }\end{array}$ & 5 & 3 & $\left((3 / 5)^{*} 100\right)=60 \%$ \\
\hline $\begin{array}{l}\text { Jika Teh Celup Prendjak 50x25x2gr } \\
\text { terjual maka G. terjual }\end{array}$ & 5 & 5 & $\left((5 / 5)^{*} 100\right)=100 \%$ \\
\hline $\begin{array}{l}\text { Jika G. terjual maka Susu Frisian Flag } \\
\text { Straw 180 ml terjual }\end{array}$ & 8 & 5 & $\left((5 / 8)^{*} 100\right)=62.5 \%$ \\
\hline $\begin{array}{l}\text { Jika G. terjual maka Teh Celup Prendjak } \\
\text { 50x25x2gr terjual }\end{array}$ & 8 & 5 & $\left((5 / 8)^{*} 100\right)=62.5 \%$ \\
\hline
\end{tabular}

Selanjutnya adalah pembentuk aturan asosiasi dari pola kombinasi 3(itemsets) seperti pada tabel berikut ini:

Tabel 8 Aturan asosiasi yang dihasilkan dari 3 pola kombinasi itemsets

\begin{tabular}{|l|c|c|c|}
\hline \multicolumn{1}{|c|}{ Rule } & Support & $\begin{array}{c}\text { Support } \\
\text { Itemset }\end{array}$ & Confidence \\
\hline $\begin{array}{l}\text { Jika Susu Frisian Flag Straw 180 ml } \\
\text { dan Teh Celup Prendjak 50x25x2gr } \\
\text { terjual maka G. terjual }\end{array}$ & 3 & 3 & $\left((3 / 3)^{*} 100\right)=100 \%$ \\
\hline $\begin{array}{l}\text { Jika Teh Celup Prendjak 50x25x2gr } \\
\text { dan G. terjual maka Susu Frisian Flag } \\
\text { Straw 180 ml terjual }\end{array}$ & 5 & 3 & $\left((3 / 5)^{*} 100\right)=60 \%$ \\
\hline $\begin{array}{l}\text { Jika G. dan Susu Frisian Flag Straw 180 } \\
\text { ml terjual maka Teh Celup Prendjak } \\
\text { 50x25x2gr terjual }\end{array}$ & 5 & 3 & $\left((3 / 5)^{*} 100\right)=60 \%$ \\
\hline
\end{tabular}

Maka, dari analisa algoritma apriori diatas didapat Susu Frisian Flag Straw 180 ml, Teh Celup Prendjak 50x25x2gr dan G. merupakan produk yang paling banyak dibeli konsumen dalam setiap transaksi penjualan, sehingga penempatan posisinya harus berdekatan. 


\subsection{Perancangan Diagram konteks}

Diagram konteks merupakan level tertinggi dari DFD yang menggambarkan seluruh input ke sistem atau output dari sistem. Diagram konteks ini akan memberi gambaran tentang keseluruhan sistem [1]

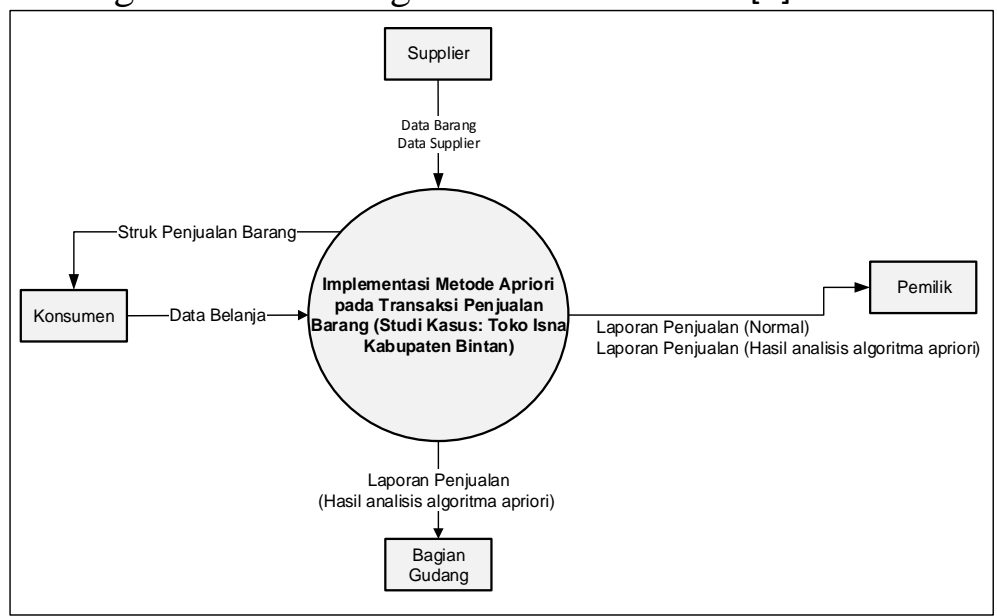

Gambar 1 Diagram Konteks

\subsection{Perancangan (DFD)}

Berikut ini adalah DFD level 0 yang dirancang pada implementasi metode algoritma apriori pada transaksi penjualan barang (studi kasus: Toko Isna Kabupaten Bintan):

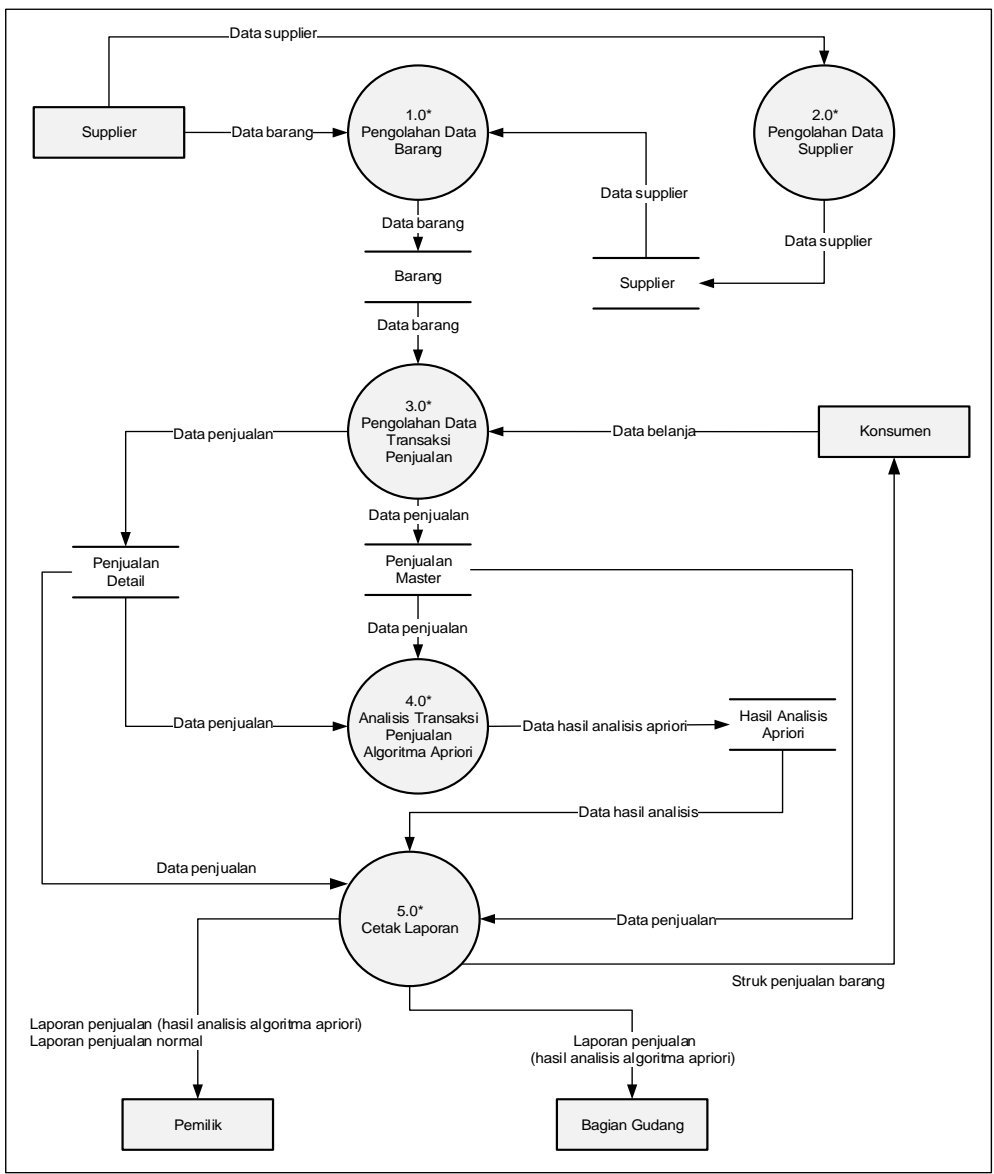

Gambar 2 Data Flow Diagram (DFD) Level 0 
Perancangan DFD Level 1 Proses 4.0 yang merupakan pengembangan proses 4 dari DFD level 0 Analisis transaksi penjualan algoritma apriori yang dapat dilihat pada gambar dibawah ini :

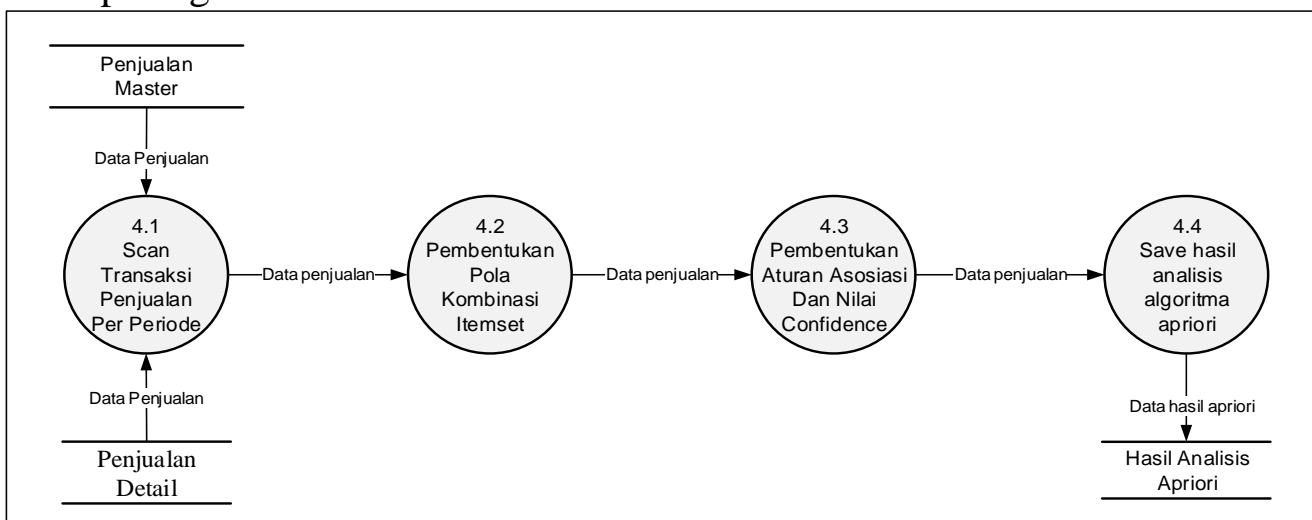

Gambar 3 DFD Level 1 Proses 4.0 (Analisis transaksi penjualan algoritma apriori)

\subsection{Hasil Studi Kasus}

Berdasarkan dari pengujian aplikasi yang dibangun menggunakan, Hasil scan transaksi, pembentukan pola kombinasi, dan pembentukan aturan asosiasi dapat menampilkan data dan menghasilkan kesimpulan barang yang dibeli secara bersamaan yaitu Susu Frisian Flag Straw 180 ml, G(gula), Teh Celup Prendjak $50 \times 25 \times 2 \mathrm{Gr}$. Penulis dapat mengambil kesimpulan bahwa dengan implementasi algoritma apriori pada transaksi penjualan barang di toko Isna kabupaten Bintan dapat membantu penyusunan tata letak barang di toko tersebut. Berikut ini adalah hasil scan transaksi, pembentukan pola kombinasi, dan pembentukan aturan asosiasi dan kesimpulan pada aplikasi yang dibangun:

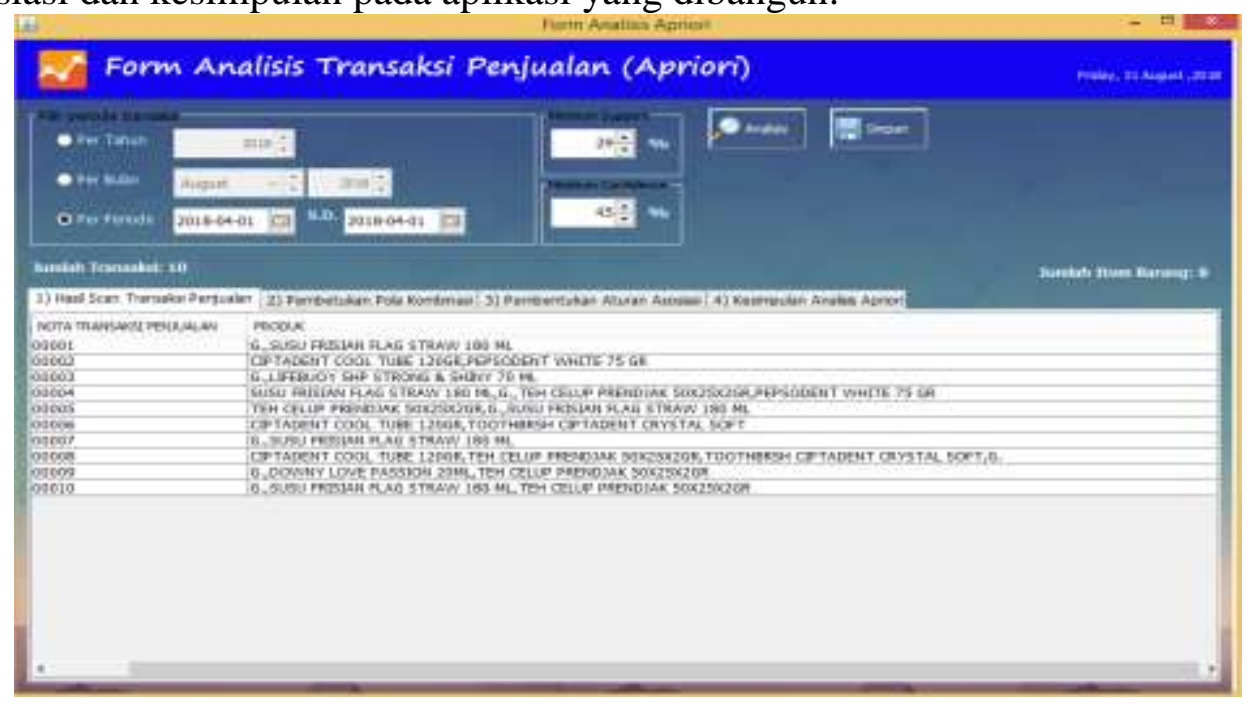

Gambar 4 Scan data penjualan 


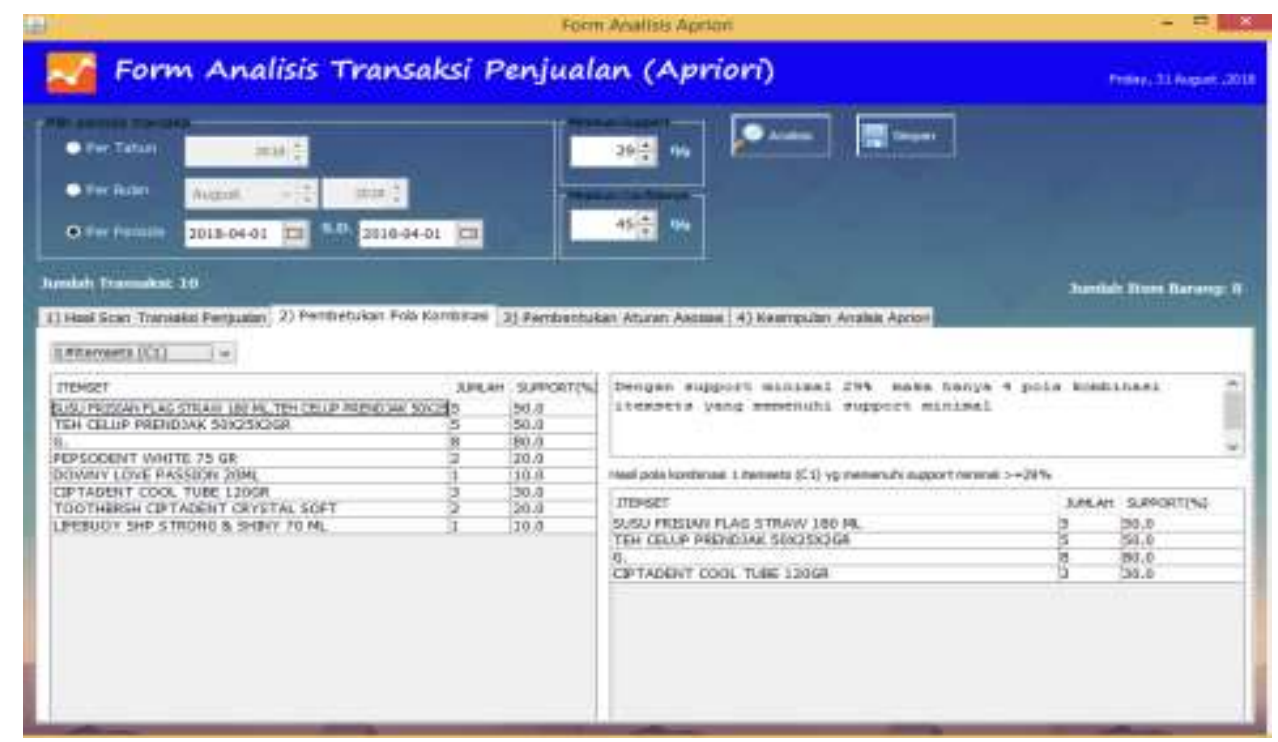

Gambar 5 Pembentukan pola kombinasi 1 itemset

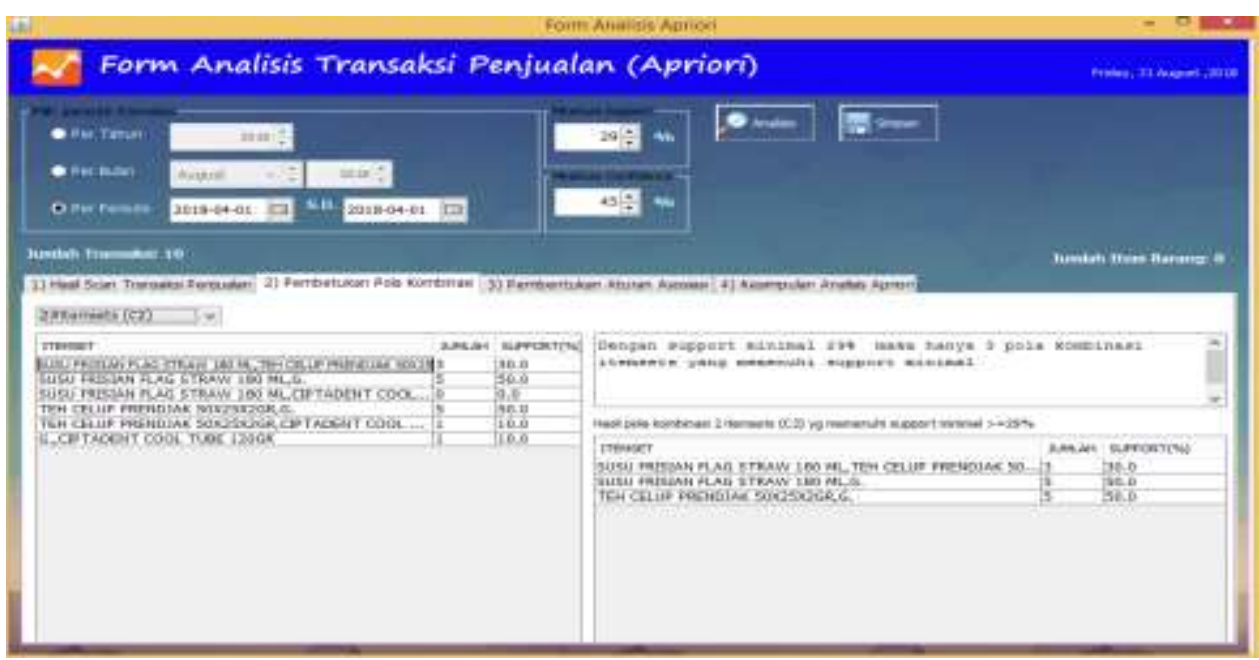

Gambar 6 Form Analisis Apriori (Pembentukan Pola Kombinasi 2 Itemset)

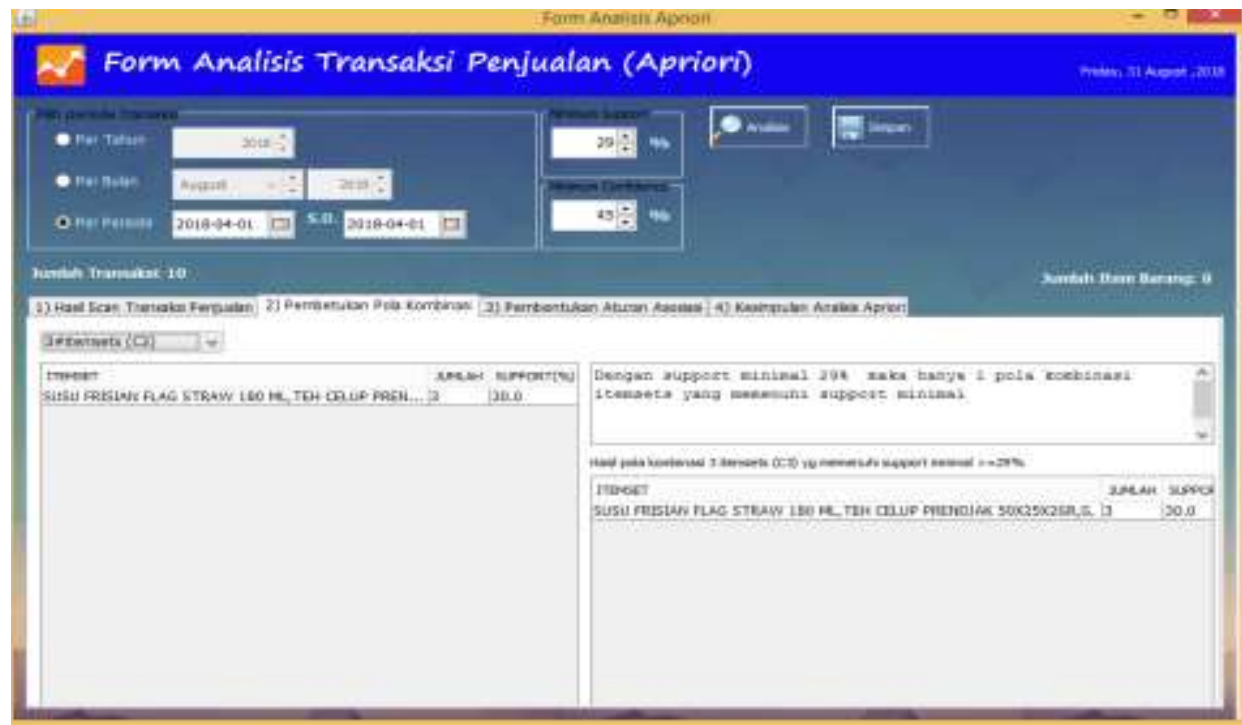

Gambar 7 Form Analisis Apriori (Pembentukan Pola Kombinasi 3 Itemset) 


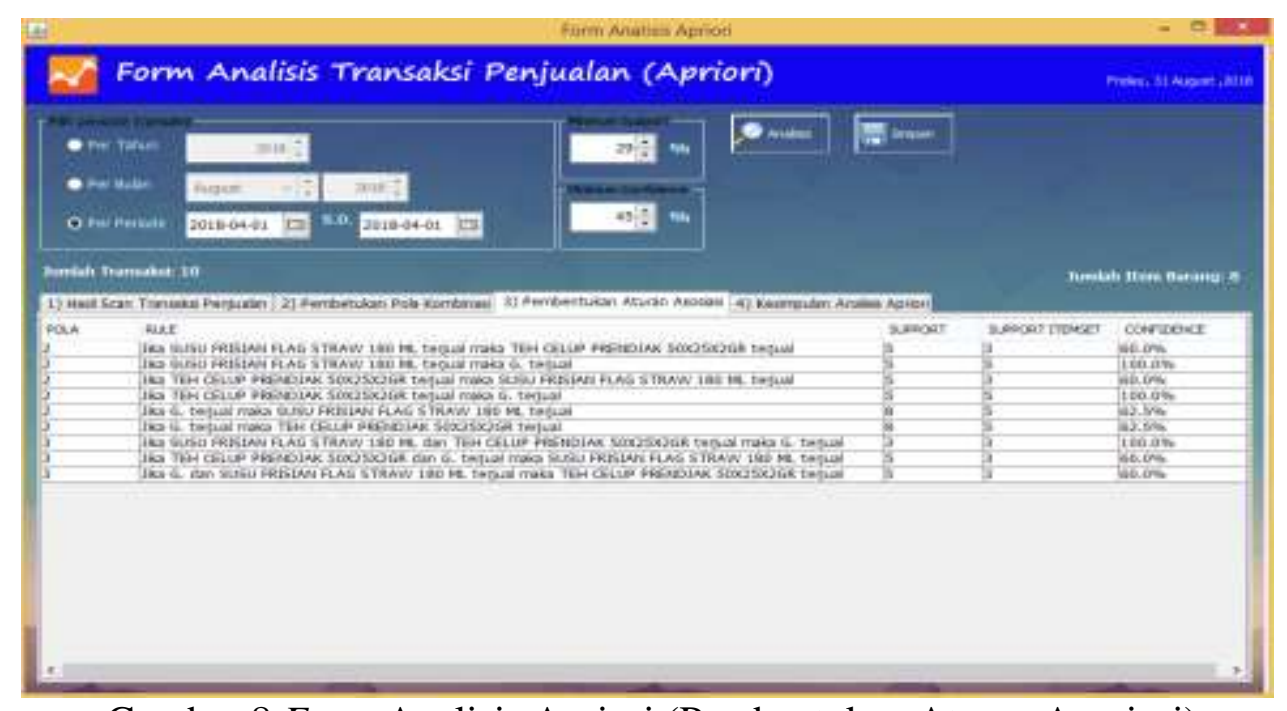

Gambar 8 Form Analisis Apriori (Pembentukan Aturan Asosiasi)

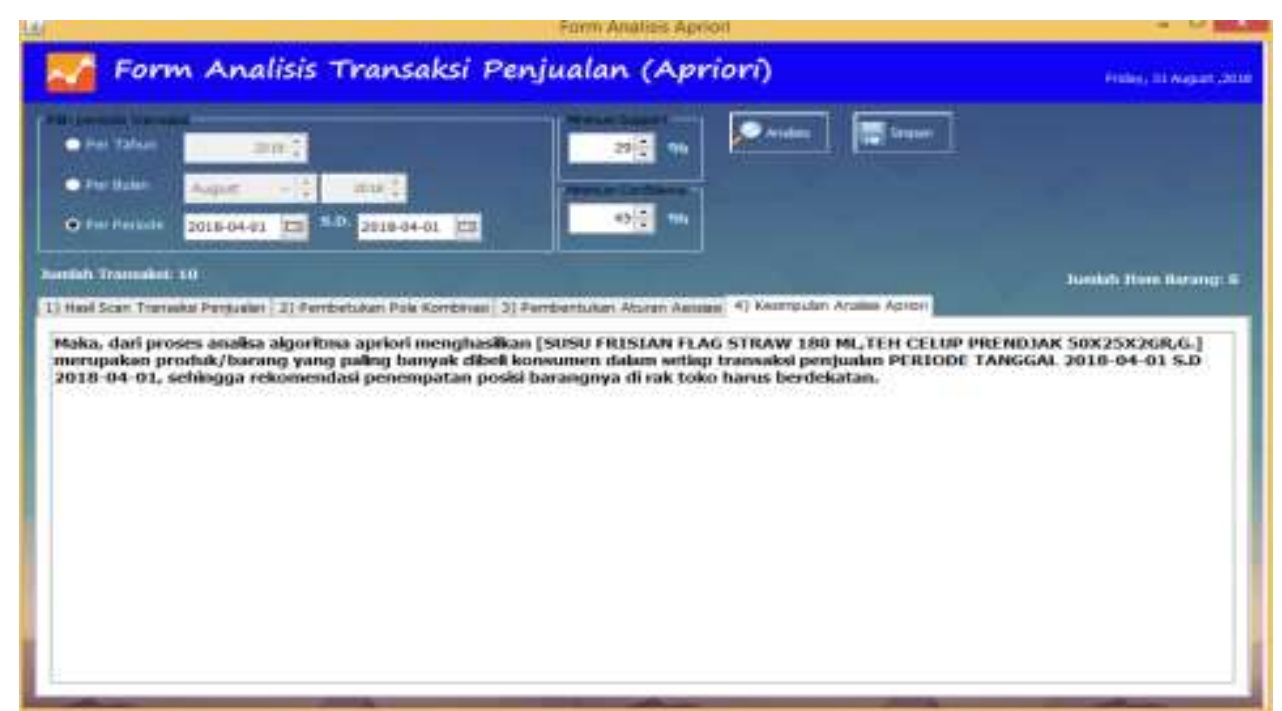

Gambar 9 Form Analisis Apriori (Kesimpulan Analisis Apriori)

\section{KESIMPULAN DAN SARAN}

Berdasarkan hasil pembahasan, output dan pengujian dari aplikasi implementasi metode apriori pada transaksi penjualan barang (studi kasus: Toko Isna Kabupaten Bintan) dapat disimpulkan bahwa :

1. Data transaksi penjualan yang menumpuk dapat dimanfaatkan untuk memaksimalkan strategi pemasaran dan meningkatkan efesiensi penempatan posisi barang pada sebuah toko dengan cara menerapkan algoritma apriori dan aturan asosiasi.

2. Aplikasi implementasi algoritma apriori pada transaksi penjualan di toko Isna yang dibangun mampu menemukan pola penjualan item item produk berdasarkan kecenderungan yang muncul bersamaan dalam sebuah transaksi penjualan. Sehingga aplikasi ini diharapkan dapat membantu penyusunan tata letak barang di toko tersebut.

3. Output dari aplikasi yang dibangun menghasilkan informasi yang memberikan pengetahuan bagi pemilik maupun pengguna untuk 
mengoptimalkan penjualannya. Barang yang mempunyai support lebih tinggi adalah barang paling laku terjual. Sedangkan barang yang mempunyai confidence yang lebih tinggi adalah barang yang mempunyai kesempatan dibeli bersamaan sehingga barang tersebut seharusnya diletakkan saling berdekatan.

Guna membantu pengembangan aplikasi lebih lanjut serta untuk mengoptimalkan hasil yang didapat maka penulis memberikan saran antara lain :

1. Aplikasi ini masih terbatas pada import data penjualan dalam bentuk microsoft excel sehingga diperlukannya pengembangan aplikasi untuk mengimport data dalam format pdf maupun format lainnya.

2. Aplikasi implementasi algoritma apriori pada transaksi penjualan barang studi kasus toko Isna ini masih memiliki kelemahan dalam melakukan scan database setiap kali iterasi didalam pembentukan kombinasi item set, sehingga membutuhkan waktu yang cukup lama dalam menganalisa data yang cukup besar. Oleh sebab itu diperlukan algoritma lain seperti algoritma fp-growth untuk perbandingan dan menguji sejauh mana aplikasi yang dibangun dapat diandalkan dalam menemukan pola penjualan item item produk berdasarkan kecenderungan yang muncul bersamaan pada database dalam skala besar.

3. Dalam menjalankan aplikasi yang dibangun, diperlukan pelatihan personel/user sehingga user bisa memahami dan mengerti output yang dihasilkan.

\section{DAFTAR PUSTAKA}

[1] Muslihudin, Muhamad dan Oktafianto, Analisis dan Perancangan Sistem Informasi Menggunakan Model Terstruktur dan UML, ANDI, 2016, Yogyakarta

[2] Vulandari, Retno Tri, Data Mining Teori dan Aplikasi Rapidminer, Gava Media, 2017, Yogyakarta

[3] Budiono., Fahmi, Amik. \& Pujiono. Penerapan Metode Association Rule Menggunakan Algoritma Apriori Untuk Mengidentifikasikan Pola Penyakit Radang Sendi. Techno.COM, Vol. 13, No. 2, 2014

[4] Nurcahyono, Fendi. Pembangunan Aplikasi Penjualan Dan Stok Barang Pada Toko Nuansa Elektronik Pacitan, Journal Speed, 2012

[5] Prawiyanti, Adita Ayu \& Triyono, Ramadhian Agus. Perancangan Sistem Informasi Inventaris, Seruni, 2013

[6] Warih Puspitasari \& Riesranty Nilandiny, Membangun aplikasi perencanaan karir online berbasis web menggunakan Metode Waterfall (Studi Kasus SMK X), Jurnal Rekayasa Sistem \& Industri (JRSI), Volume 3, Nomor. 2, 2016 
[7] Buulolo, Efori. Algoritma Apriori pada Data Penjualan Di Supermarket, Seminar Nasional Inovasi dan Teknologi Informasi, 2015 [Online] Tersedia di https://www.researchgate.net [4 Maret 2018/20.20 WIB] 


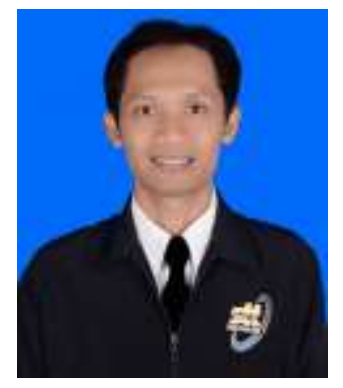

1. NIM 3215622

2.Nama Lengkap

: Iwan Purnomo

3. Judul Skripsi

:Implementasi Algoritma Apriori pada Transaksi Penjualan Barang (Studi Kasus: Toko Isna Kabupaten Bintan) 